\title{
Precarious Living: Assessing the disaster risk vulnerability of selected informal settlers in Dasmarinas City, Philippines
}

\author{
Maria Virginia Aguilar * \\ Social Sciences Department, De La Salle University-Dasmarinas. \\ Dasmariñas, Cavite, Philippines 4115.. \\ * Corresponding Author. E-mail: mgaguilar@dlsud.edu.ph
}

\author{
ARTICLE INFO \\ Article History \\ Received: \\ 24 March 2021; \\ Revised: \\ 31 March 2021; \\ Accepted: \\ 31 March 2021; \\ Available Online: \\ 13 June 2021

\section{Keywords} \\ Disaster risk; \\ Informal settlers; \\ Precarious living; \\ Slum dwellers
}

\begin{abstract}
From the perspective of disaster management, the proliferation of slums and informal settlers poses a serious problem because their economic status inadvertently drives them to spaces unsuitable for housing. The informal settler often resides in areas prone to flooding, seismic activity, and landslides exposing them to a vicious repeat cycle of destruction and loss of life. Sitio Bato, a newly-formed informal settlers' community in Dasmarinas City, Philippines, is a case point. Situated near a creek and without electricity and water connection at the start of the study in 2019, the residents are seemingly susceptible to disaster hazards. Against this backdrop, this study seeks to discuss the knowledge, attitudes, and practices of the residents of Sitio Bato regarding their vulnerability to disasters and the views of selected local government officials regarding the self-assessment of the informal settlers. Through the survey, a method using a questionnaire with household heads as respondents, and key informant interviews of local leaders, the following findings were notable in the study. First, the residents were knowledgeable of preventive mechanisms of floods, such as the important function of trees and the proper waste disposal techniques to exclude waterways. The barangay officials recognize the residents' neighborhood organization, and hence, their attendance to seminars/training on disaster management might have helped. Second, in terms of attitude, it is innate for the informal settlers to care for their neighbors, and thus, it is part of their daily activity to check on each other's families. The lack of electricity encourages them to stay outdoors and talk to each other, strengthening their bond. Third, in terms of practice, trash disposal to the creek is not done, and hence, water from the creek flows without obstruction. A few Sitio Bato residents collect recyclable waste coming from communities in the upper part of the creek. Overall, residents do not see their living in Sitio Bato as precarious or hazardous. Local officials generally perceive the city's informal settlers as "privileged" because the services offered by the city government are received by everyone, regardless of the legality of their residence..
\end{abstract}

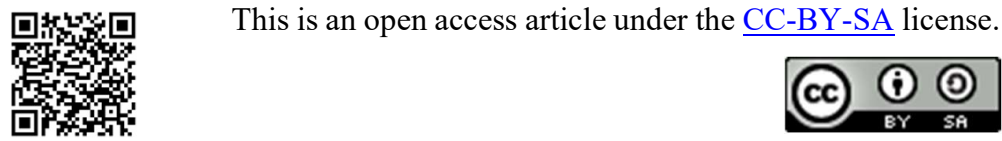

How to cite:

Aguilar, M. V. (2021). Precarious Living: Assessing the disaster risk vulnerability of selected informal settlers in Dasmarinas City, Philippines. Harmoni Sosial: Jurnal Pendidikan IPS, 8(1), 13-25.

https://doi.org/10.21831/hsjpi.v8i1.39604 


\section{INTRODUCTION}

Around the world, more than a billion people reside in marginal and informal settlements, many of whom do not have access to basic services, and very frequently in high-risk areas such as along rivers, railroad tracks, near garbage dumps, under bridges, and beside industrial establishments (UN-Habitat, 2003). Collectively referred to as informal settlers or slum dwellers, they often live on vacant private or public lands they don't own without the owner's consent. These locations are often unoccupied because they are at risk of flooding, landslides, traffic accidents, and health hazards. Many informal settlers are characteristically unemployed, although some work as domestic helpers, tricycle and jeepney drivers, part-time construction laborers, street-side vendors, recycling foragers, and scavengers (Palanca, 2014).

In the Philippines, the UN-Habitat reports that as of 2012, of the 92 million Filipinos living in cities such as Metro Manila, an estimated 3.1 million of them lack secure land tenure, and 2.7 million are informal settlers living in slums (Karaos, Nicolas, \& Rabacal, 2011). The slum population is increasing at an annual rate of over $3.5 \%$ compared to the urban population growth rate of $2.3 \%$ for 2000-2006. The UN-Habitat report projects that by 2050, the slum population in Metro Manila alone will have reached over 9 million. Moreover, about 32\% of this population are poor with incomes below the 2020 national poverty threshold of around P20,000 (US\$400) annual per capita, while $12 \%$ are in extreme poverty about the $\$ 1.90$ international poverty line in the same year.

The proliferation of slums and informal settlers is a major problem in the Philippines. Akin to many archipelagic countries, the Philippines suffers from a land deficit; housing is difficult but economically unfeasible for the poor, much so for those in the urban areas (Karaos et al., 2011). Thus, the urban poor is inadvertently driven to spaces otherwise unsuitable for housing. These danger zones are prone to flooding, seismic activity, and landslides. Living in these areas exposes informal settlers to a vicious repeat cycle of destruction and loss of life. Their vulnerability to disaster events is often compounded by a lack of infrastructure, environmental degradation, and increasing challenges exacerbated by climate change and sea-level rise (de Leon \& Pittock, 2017).

This is not to discredit the existence and role of the government's National Disaster Risk Reduction and Management (NDRRM), whose programs are considered as "the principal guide to disaster risk reduction and management (DRRM) efforts to the country...." aimed at enabling "safer, adaptive and disaster-resilient Filipino communities toward sustainable development." From reactive to proactive management of disasters, the government aims to achieve increased awareness and understanding amongst the Filipinos, with the end in view of their people's resilience and decreasing their vulnerabilities. However, the problem remains when the illegality of residence is factored in.

Several studies have shown that informal settlers have been especially disadvantaged due to their place of residence. For example, Lo, Franta, Roa-Quiaoit, and Narisma (2016) writes that one core factor of the disaster in Cagayan de Oro (south of the Philippines) was the widespread presence of informal settlements on the banks of the Cagayan River. Not only were many of those killed residents of informal settlements, but the flood and subsequent "no-build zones" permanently displaced tens of thousands of informal settlers. Similarly, in Marikina, during continuous heavy downpours or typhoons in 2013, the river level rose so much that informal settlers had to vacate their homes and stay in evacuation centers until the floodwaters receded (Iglesias, 2008). Also, one cannot exclude the Payatas trash avalanche triggered by heavy rains in the year 2000 that took the lives of 288 people, buried hundreds of homes of slum dwellers, and displaced close to 1,000 waste pickers/scavengers (Gaillard \& Cadag, 2009). These indicate the precariousness of the lives of informal dwellers.

Locally, the phenomenon of accommodating informal settlers or dwellers is deeply rooted in Dasmariñas City's past and has persisted to the present. The city has been at the receiving end of informal settlers since the 1970s. A cursory inspection of the residences of the informal settlers scattered in different barangays (barangay is the smallest political unit in the Philippines) would indicate that this has not been appropriately addressed. Not only are they looked upon as eyesore, but anecdotal evidence says that they are also excluded from services normally enjoyed by regular residents. This exclusion is especially felt when calamities and help are provided for the legitimate residents of barangays as validated by barangay ID or voter's ID. 
In particular, the case of Sitio Bato, a newly-formed informal settler's community, seems to be a disaster waiting to happen. Situated near a creek where garbage is thrown and without electricity and water connection (at the start of the study in 2019), the residents living are highly susceptible to health hazards. From 10 makeshift houses in 2018, it now has doubled. Informal interaction with the residents indicates that the number will continually rise as their relatives from different provinces are interested in joining them at Sitio Bato. Against this backdrop, the study aims to describe the spatial location of informal settlers, describe their knowledge, attitudes, and practices related to disaster management, and their self-perception of vulnerability to disaster.

In the early 1970s, relocation and resettlement commenced in Cavite, Philippines, and continued up to the early 1980s (Apilado-Cañete, 2007). Cavite was handpicked as a pilot site for resettlement because of its important role in developing the Calabarzon region. In particular, due to its strategic location, Dasmariñas was targeted as a key area for the setting up of economic zones, where industrial estates would be developed through the establishment of Dasmariñas Bagong Bayan (DBB). It was conceived to be the pilot project for a model human settlement not only in the Philippines but also in the Asia-Pacific region. First Lady Imelda Marcos, formally heading DBB, the goal was to decongest Metro Manila by building a self-contained community for its growing number of informal settlers and urban low-income families. The relocated families were awarded lots measuring 90-200 square meters through interest-free loans in which a minimal monthly amortization would be paid for 25 years. There were fifty (50) barangays designated for relocation. Before the start of resettlement, some of these barangays already had numerous residents. Some barangays not chosen as resettlement sites also had relocatees living within them because it was common to sell or have one's house rented to other people. It is important to note then that although, officially, there were only 50 barangays allotted as relocation sites, many relocatees live in barangays not formally designated for relocation.

Many of the relocatees were not original dwellers of Metro Manila. For example, in barangay Area I, the relocatees were migrants originally from the provinces of Masbate, Leyte, Sorsogon, and Agusan del Norte (Apilado-Cañete, 2007). From these provinces, they settled in Sampaloc, Pandacan, Paco, or near the railroad tracks of San Lazaro and banks of Pasig River. As informal settlers, their makeshift houses were eventually demolished, and when they were offered relocation in Cavite, the chance to have their own home proved irresistible. DBB, more popularly known as "area," has gained an unsavory reputation for being crowded, disorderly, and crime-infested. As a neighborhood, the "area" is notorious for being the residence of drug peddlers and addicts and where fights, drinking sessions, gun shooting, stabbing incidents, and burglary are common occurrences on the streets. New settlers of the city think that the "area" is not safe for children. There is a constant clash between the original settlers (relocatees) and the new settlers, who mainly bought their lot from some original settlers (Apilado-Cañete, 2007). New settlers who are well-off fortified their residences with walls, gates, and window grills because burglaries are commonplace, and the perpetrators are believed to be the original settlers. The new settlers are relatively better off than the old ones.

Non-residents of "area", or those coming from barangays not included in the relocation in the 1970s, discriminate against them, saying that "area" residents are squatters and criminals from Manila. All these indirectly compel new settlers to seek out areas where they can live in peace with relatives/kins or long-time associates. With informal settlers mostly as residents, it is easy to exclude them from social services, including those that are given when disasters arrive. This study anticipates the devastating effect of disasters (when they come) to the Sitio Bato community, given that its population is increasing. Hence, this study will explore their knowledge, attitudes, and practices regarding disaster risk to determine how vulnerable they are to disasters.

In particular, the research questions for this study are as follows: What are the characteristics of Sitio Bato as a spatial location of informal settlers?; What are the knowledge, attitudes, and practices of the informal settlers that form their self-perception of vulnerability to disaster risk? How do local officials assess their vulnerability to disaster risk? The responses to these research questions will shed light on the disaster risk of this vulnerable community of informal settlers. 


\section{METHOD}

The study seeks to discuss the knowledge, attitudes, and practices of the informal settlers of Sitio Bato regarding their vulnerability to disasters and the views of selected local government officials regarding the self-assessment of the informal settlers. To understand the self-perception of vulnerability, primary data was collected through a survey of all household heads and key informant interviews with their neighborhood organization. The bulk of the results and discussion came from the survey. Questions focused on their current socioeconomic status, knowledge, beliefs, and practices related to disaster risks and management, and their self-perception of vulnerability. The key informant interviews with the neighborhood organization were meant to deepen the survey results. Furthermore, key informant interviews with local officials of Barangay Salitran 4, the local government, specifically from CDRRM, were facilitated. Their responses were examined thru thematic analysis. Observations using a checklist were also done to substantiate the responses of the household heads. Moreover, valuable information was gathered during the November 2020 Assembly of Salitran 4 residents presided by their Barangay Chairman.

The following framework guides the data analysis of this study culled from different studies tackling the experiences of the vulnerability of informal settlers.

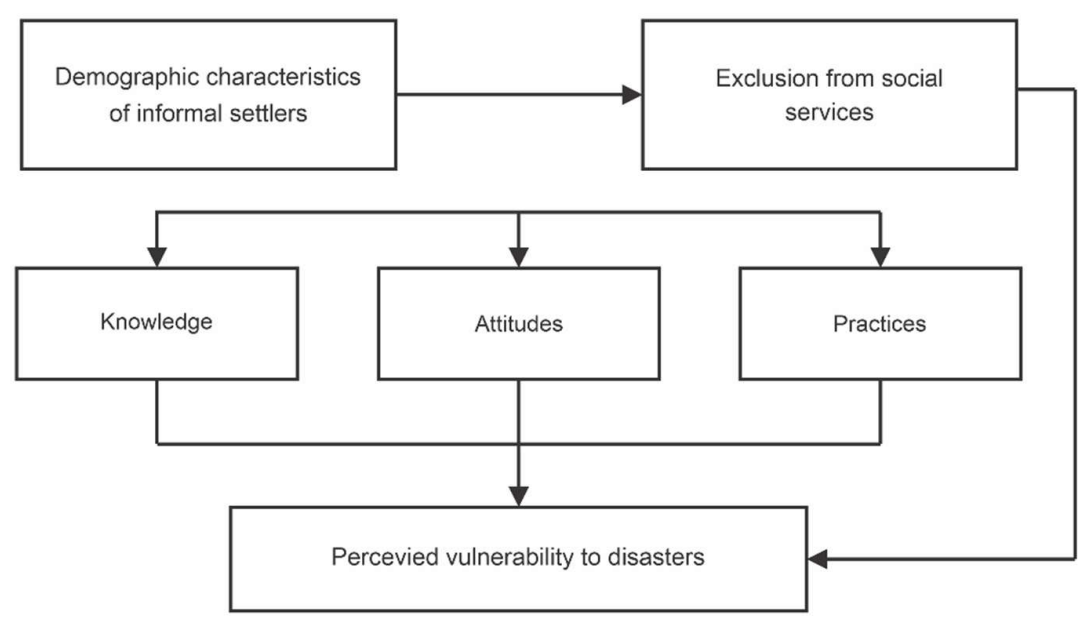

Figure 1. Framework of The Study

The perception of the informal settlers will be discussed against the backdrop of the theory of social exclusion. Social exclusion has been defined as "the inability to enjoy social rights without assistance and the inability to have access to the benefits the society offers (Kamerman, Neuman, Waldfogel, \& Brooks-Gunn, 2003). It comprises not only the lack of access to goods and services which underlie poverty but also exclusion from security, justice, political representation and citizenship (Rodgers, Gore, \& Figueiredo, 1995).

In elaborating on the dynamics of social exclusion, Castel (1997) argues that the causal relationship between poverty and disadvantage and wider inequalities must be recognized: the linkage between the experience of those at the margins of society and the fundamental working of societies. Hence, in this case, the exclusion of the informal settlers from government services is projected to make them creatively respond to disasters independently, without thought of the governmental role. However, it means that their vulnerability is higher than most people. 


\section{RESULT AND DISCUSSION}

\section{Sitio Bato as a Spatial Location of Informal Settlers}

\section{The first settlers}

The name "Sitio Bato" is relatively new and has not been used popularly () yet, even among the residents, more so among the people outside the community, who still call the area "an excess lot." Using Sitio Bato is preferred by the Samahan ng mga Magkakapitbahay sa Sitio Bato (Neighborhood Organization of Sitio Bato) or Sambahayan, the recognized (by the barangay council) residents' organization as they explained that:

"It's more pleasing to the ear as they are not immediately labelled as non-owners of land, or squatters."

The residents decided to name their place Sitio Bato because large stones were scattered all over before, but these are no longer visible this time. Aling Nora, 49 (not her real name), the vice president of Sambahayan, relates that it was in 1994 when "Apo Luis" (not his real name), the first settler, who was a carpenter working at the nearby gated residential subdivision named Town and Country, was told by their chief engineer that the carpenters and their families could transfer here, after having been allowed to settle temporarily in bunkhouses inside the subdivision while construction was going on.

When construction was completed, and the turnover of the houses ensued, the chief engineer did not want to let go of his workers just yet, anticipating that repairs and minor carpentry work still needs to be done which might be requested by the recently transferring homeowners. Stories say that the engineer knew who the owner was and asked permission from him. This owner obliged graciously as his family is rich and are all living abroad, and was even grateful that there will be caretakers. This story has been passed on without attempts at establishing its veracity.

Apo Luis, now 89 years old, planted vegetables and fruits. Her daughter, Aling Mila (not her real name), 65, still a resident in Sitio Bato pointed to the trees and lush vegetation during the interview and proudly said:

"Father is kind, so, look at the bamboos, and mangoes, the large trees, he was the one who planted them."

Apo Luis brought his entire family in 1994 and has lived here since then, until now, although his old age prevents him from actively moving around. When his children got married, they also settled here. The families of the rest of the construction crew invited by the engineer also opted to live here. No fees such as rent have been collected ever since, and the barangay chairmen since then until the present one knows of their situation as informal settlers. They registered in the barangay as residents, and their houses at present were marked to serve as "control numbers."

Aling Mila shared that a tacit agreement amongst the neighbors limits the number of houses to 13 and informs all neighbors if new house members have been invited to live with them. The abovementioned description of the beginnings of a slum neighborhood is no different in other countries. Aliu, Akoteyoa, and Soladoye (2021) and Marmot (2005) describe a similar scenario in many parts of the world, particularly Nigeria's case of slum dwellers, which mirror what Dasmarinas City has. As reiterated by both studies, it is a stark reality that many urban residents live on the margins of precarious poverty, infrastructural decay, and social deprivation.

\section{Present Scenario}

Although Sitio Bato is a 2-minute walk to the highway, the location is nondescript. For a long time, few people knew of the existence of this place, perhaps only the residents and the barangay officials of Salitran 1. From the highway, the houses cannot be seen. Instead, the trees above and stream down below shroud the whole area of fewer than one sq. $\mathrm{km}$. A stream separates Sitio Bato from the rest of the community, and so, the residents on their own made a bridge out of bamboo. Over time, the bridge became weak and slippery, and so, the residents collectively ask the barangay chairman for assistance, and it was granted, albeit the financial help was lacking. They were able to 
raise the remaining amount, so, at present, the bridge is retrofitted: the bamboo is still there but enclosed in metal and other sturdy material to make the bridge withstand heavyweight. However, only two-wheel vehicles can enter the place.

Up to now, no one knows for sure who is the owner of the lot. There's a new rumor circulating that no one owns the area. Even Aling Mila, the daughter of Apo Luis, is now unsure because no one has come forward to claim or to demand payment. This is perhaps why some of the first settlers fenced apart and planted vegetables and fruit-bearing trees. The president, Antonio (not his real name), 42, said:

"Maybe they thought that later, no one will really claim, and so, anybody can just claim. They just did it ahead, advanced."

Interestingly, two new houses were built, and are owned by barangay officials. The residents expressed ambivalence:

"It's good there's someone from the barangay, so that if there's any issue, it will easily reach the barangay officials, but, maybe, we'll grow bigger and bigger here, and then, everyone knows everyone here, but now, there's people we don't know."

The residents of Sitio Bato are somehow secured in the idea that they are accepted as part of barangay despite there being informal settlers because they have been organized through the initiative of an SK Kagawad, namely Janette Lacson (not her real name). An election was held to organize them and ensure representation whenever barangay meetings are held. The barangay chair swore them in in 2019. Kagawad Lacson explains that this recognition is important because whenever there are meetings, the people in Sitio Bato are included and represented appropriately.

The importance of organizing the neighborhood to elicit participation and the consequent sustained support from the residents cannot be overemphasized. The importance of local participation has been pointed out as an integral part of unity among community folks in a 2019 study by Sejati, Hasan, and Hidayati (2021). On the level participation in efforts mount Kelud eruption disaster mitigation in East Java and the 2020 research of Bahagia, Mangunjaya, Wibowo, Rangkuti, and Alwahid (2020) entitled Leuit and prohibition forest: Indigenous knowledge of Urug community resilience.

\section{Pressing problems}

Two main problems are experienced by the community: first is the lack of electricity and second, the lack of water line. Since 1994, Sitio Bato has not been given an electricity line, despite some clamor, albeit informal and not steadfast. The residents explain that:

"It's hard to demand because we don't own the land here, how can we apply? But last year, chairman said we can already apply. Meralco is amenable, but we are to buy the line that will be installed outside. I have already canvassed, and we will just contribute, but the pandemic came, I can no longer attend to it."

When asked if the neighbors are amenable to it, Aling Nora said,

"If they contributed to the strengthening of the bridge, as I was able to collect 5 thousand. People here are kind."

Because of the social distancing protocols, students need light at night to continue answering their assessments sent by the schools they are enrolled in. What every household does is use chargeable lamps using power banks. Every day, they go to their friends or relatives within Dasmariñas who have electricity, and they charge their power banks from relatives in Dasmariñas for Php20 /full charge. One can hear music blaring in a neighbor's house, and a few residents said they would much rather prefer silence. They insist they can live without electricity, but because of the module classes (due to the social distancing protocol that the Covid 19 pandemic brought), which their kids cannot finish during the day, they need to have light at night. However, for the residents, the water problem is much more pressing. 
Just recently, the Gonzales, who now has five houses, as the children of the original settler have married, have applied for a water line, and the barangay officials supported them, as the officials thought they were representing the sentiments of the residents. Sambahayan officers were slighted:

"We were supposed to have a meeting to determine how we will have supply of electricity, and we plan as officers to ask everyone, the neighbors. We were surprised they already have a line."

Instead of feeling happy that they need not buy water outside of Sitio Bato, the residents were crestfallen because the Gonzales families charged 5 pesos per blue container (20 liters). On average, each of the 13 families uses ten containers a day. Since five families are part of the Gonzales family granted the waterline, eight families buy from them. Aling Nora and Aling Mila expressed dismay:

"It is too expensive. They made it a business. It is as of our being neighbors was no longer considered, they just want to take our money, and they know everyone is experiencing hardship."

Residents expressed that heavy rains are seen as great opportunities to experience many "water activities" and are not causes of fear.

"You will see all the residents going out, washing blankets, curtains, and other big things. And we save water for bathing, washing, flushing so that what we will buy is only for cooking and drinking."

The abovementioned hardships are not unique to the Philippines. Marmot (2005) noted that slum residents are regularly faced with inadequate access to safe water, insufficient access to sanitation, poor structural quality of housing, overcrowding, and insecure residential status.

\section{Demographic characteristics}

As of November 16, 2020, 83 persons in 14 households (with mostly 5-9 members) live in Sitio Bato. All of them are relatives/close friends of the original or first settlers. The poverty of the residents is evident from the houses, of which the materials are made of scrap and the foundation weak. Moreover, four families still do not have toilets and relieve themselves at night by digging holes directly onto the soil. The residents assured that fecal matter is covered very well, and so there is no smell. The residents further explained that no one has gotten seriously sick, especially when sanitation is considered the cause. A few cases of colds, cough, and occasional fever were reported. The residents explained that they often clean their surroundings, both their yards and the common areas.

Most of the residents have been living here for more than five years, and their families are originally coming from Luzon, specifically in the provinces of Cavite and Bicol. Unmistakably, their religion, mostly followers of Iglesia ni Kristo, has helped maintain the few numbers of residents and prevent the influx of outsiders: they are not just neighbors. They also go to the same church. Looking at the family income of the residents, it is no surprise that the heads of the family earn marginally given their employment/ job. A few enterprising residents took to raising chickens, ducks, and pigs to augment the family income. This seems ideal because a stream traverses through, so ducks can easily wade in the water. With pigs, chickens, and ducks, the others who started gardening stopped because their plants were ravaged and maintained a good relationship. They needed to give way.

Indeed, the lives of the informal settlers are mired with poverty and its concomitant difficulties. As the UN Human Settlements Programme (UN-Habitat) observes, informal settlements are

"Residential areas where the inhabitants have no security of tenure vis-à-vis the land or dwellings they inhabit, and where the neighborhoods usually lack, or are cut off from, basic services and city infrastructure, and where the housing may not comply with current planning and building regulations, and is often situated in geographically and environmentally hazardous areas." (UN-Habitat, 2003). 


\section{Knowledge, Attitudes and Practices of The Residents and Their Self-Perception of Vulnerability to Disaster Risk}

\section{Knowledge}

The residents' bank on the popular notion that trees prevent flooding, and hence when asked about their views regarding their vulnerability to disaster, the response of Antonio, the president said:

"Lots of trees are here, and that is good. It does not just make the surrounding cool but also prevents flood."

The belief that the trees are surrounding prevent inundation of water was frequently mentioned. There was just one instance, in 2018, that the residents noticed that the water of the creek rose, but the trees protected them. Aling Mila, 65, who is one of the earliest to settle, said:

"With God's help, there are no houses that got so devastated, with all the bamboos barring the wind."

Aling Nora confirmed this saying that,

"Water does not rise because there is no trash blocking - there are people picking plastics. Isn't it that there was a typhoon that came? It destroyed just a bit my kitchen, the fence of the house in front."

Rommel (not his real name), 17, also expressed that he and his friends of the same age do not feel afraid because their houses are slightly higher than the creek. Pointing to the creek, he said,

"We're on higher ground, and no one throws trash there, so the water flows and does not get stuck. The trash you see came from up there, not from us here."

\section{Attitude}

Overall, no residents fear the onslaught of typhoons or any natural calamities that might visit them. Several reasons account for this. First, there has never been flooding, and hence, the residents do not think there will ever be.

The Sambahayan president said:

"Strong typhoons came and has killed many Filipinos. With God's mercy, Sitio Bato still stands. Though our house structures are not so strong, yet, nothing has been devastated."

Another reason cited is the support of the barangay officials. The residents said they have always been given help that others, the non-informal settlers, receive. During the pandemic period, Aling Nora said,

"I am the one attending the meeting, so I know that what is given to those in subdivisions is the same with what we receive."

Finally, neighbors say that having known each other works to their advantage. It is innate in them to care for their neighbors. Thus, it is natural that part of their daily routinary activities is talking to each other, which is inevitable, especially since most stay outside of their house after their chores. Without electricity, they have no television sets that may encourage them to stay indoors. During heavy rains, it is common for them to check on each other and offer help when needed. Overall, the residents say that there are no problems that bother them, except the recent water issue.

\section{Practices}

Noticeably, the shared space, such as the pathway, is clean and free of litter. The residents put effort into keeping things tidy. Likewise, the creek has no obstruction, and water flows through. According to Aling Mila, 65,

"I am just here at home the whole day. We clean the creek because there's money in it. In three months, I only earned 148 pesos. My grandchildren are here. We recycle here." 
The residents said that they had not encountered any program on disaster risk management that the barangay offered. However, they are very supportive of the initiatives of the barangay, and their participation is ensured because if there is a meeting, they are fetched. Some people from their neighborhood attend for them. When asked point-blank if they feel they are discriminated against, they said no, as any barangay project includes them. But there are no specific programs for them which is not a problem because Rey (not his real name), 18, said,

"We are okay here. There's no problem. There's no fighting here. It's just quiet. The only problem is the water supply which is now turned into a business."

In the recent typhoon, barangay officials sent Aling Nora a message, telling her to report any concern that needs immediate action. They were also told that a vehicle is just a text message away if there is a need to evacuate. Aling Nora said:

"When typhoon Rolly and Ulysses came, they came to us and asked us if we want to be evacuated. No one went because we're not afraid. It's not so strong. We also think that we have our way of managing. But there is a number we can call if there's a need to evacuate us."

The residents also divulged that even without electricity, each family has a cellphone and power banks. So, it is easy for them to call help when needed. In a similar study in India, an acceptable level of awareness and attitude towards disaster mitigation among slum dwellers is seen. Bhattacharjee (2018) divulged that most residents are aware of the necessity of proper waste disposal because it can cause damage to human health and the environment. This finding is resonated among the informal settlers of Malaysia located along the riverbank of East Jakarta. The closely-knit relationship developed among them created a perception of secure tenure in the settlement, which has generated increased community investment in infrastructure and house consolidation (Winayanti \& Lang, 2004).

\section{Local Officials' Assessment of The Informal Settlers' Vulnerability to Natural Disaster}

Dasmariñas City has an established hierarchy of office tasked to handle and manage matters relating to natural disasters and otherwise. The City Disaster Risk Reduction Management of Dasmariñas (CDRRM) is the office that functions as the umbrella structure for the whole city's disaster stakeholders. Under it is the Barangay Disaster Risk Reduction Management Council (BDRRMC). The barangay captain has usually appointed the head, and hence, it is easy to cascade the projects of the CDRRM to the BDRRMC. The present CDRMM officer in charge is Mr. Reynor Calado, who assumed office in 2020 and is currently holding his office on the first floor of the Dasmariñas City Medical Center, which is partly because he also heads the ICT of the hospital, the Engineering, and Maintenance of the City plus a host of other offices related to ICT programs (the city's CCTV, security, radio room, etc.).

The program of Dasmariñas City is composed of three integrated parts. The first is the predisaster program which includes decisions on budget allocation for the program, procurement, and maintenance of resources and equipment such as emergency tools and vehicles, loudspeaker, tarpaulin, and other early warning systems/devices. Likewise, decisions on what seminars and training to give barangay officials and school personnel, and students, including orientation of the block leader system of information dissemination, are included here. A block leader is a crucial person assigned and tasked to monitor the residents under his block, and hence, he is the link between the barangay officials and the residents. This makes the flow of information efficient and centralized. The second part includes activities done during actual disasters, consisting of rescue, evacuation, and food, clothing, and shelter to affected residents. The third part is on post-disaster activities done by the barangays, including the extension of help in rebuilding destroyed homes and rehabilitating affected residents, offering livelihood training, and evaluating and replanning their programs, if needed.

When asked if Dasmariñas is disaster-prone, OIC Calado explains that a change of perspective regarding how the disaster is viewed is imperative:

"Our usual response to disaster is on recovery. This is acceptable because recovery is needed, but wouldn't we want to prevent disasters? Instead of thinking that they're bound to happen, we 
must deal with the destruction, deaths, etc. As head of Dasmarinas DRRM, I prefer education, seminars, and ensuring that when infrastructures, for example, are built, they are done right. We need preventive programs."

He further explained that the recent deaths in a residential subdivision in Dasmariñas were preventable. Three persons died- a mother, father, and a baby because the wall enclosure of a newly built subdivision collapsed and toppled over their bunkhouses where the construction workers and their families reside:

"I realized how unprepared Dasmariñas is. We had no equipment to dig fast, and people were not trained to respond immediately but safely. We had no people who assisted the survivors, to each his own. I vow that under my term, we have to address these important concerns."

Barangays implement a "block leader system" of information dissemination, not just during disasters but for other programs that need to be cascaded to the barangay folks. Before the pandemic, it is usual that during flag ceremony held every morning in front of the barangay hall, the barangay officials make announcements to a select group of people called the "block leaders" who represent a particular block of the barangay. These block leaders are then expected to communicate the information that they have to their neighbors in their blocks. During regular monthly meetings, block leaders also are required to attend.

The abovementioned programs of Dasmariñas City align with the Philippine government's National Disaster Risk Reduction and Management Plan (NDRRMP). The NDRRMP covers four thematic areas, namely, 1.) Disaster Prevention and Mitigation; 2.) Disaster Preparedness; 3.) Disaster Response; and 4.) Disaster Rehabilitation and Recovery. A pressing concern, however, is the published Commission of Audit's (COA) assessment of Dasmariñas City's Annual Audit Report of 2019 on the programs:

"Local Risk Reduction Management Fund LDRRMF) totaling Php 4,275,660.00 was spent for programs, projects, and activities that were not related to disaster risk management, contrary to the national disaster risk reduction management council (NDRRMC), Department of Budget and Management (DBM), and the Department of the Interior and Local Government (DILG) Joint Memorandum Circular No. 2013-1, thus defeating the purpose for which the fund was created."

When asked to comment on this, OIC Calado (not his real name) said COA has written a letter addressed to his office seeking a written explanation with attachments to address this concern. He emphasized that it is not good management to divert funds. Since his assumption of office in 2020, he is aware of the different concerns he has to attend to, including this. Presently, he is consolidating responses from other offices to justify the diversion of funds. When asked if perhaps it is because there are no real disaster threats in Dasmariñas, given that in the past, Dasmariñas City has none to very few casualties, even with supertyphoons, OIC Calado believes otherwise. For OIC Calado, the past year has informed what needs to be improved by the city government regarding disasters. He explains,

In 2019, me mga bagyo, me mga earthquake, pumutok ang Taal, tapos ng pandemic. It has made me see things in a different light. The question in my mind always is - is Dasmariñas City ready? Are we responding well? Are we equipped? Sadly, it's negative." (In 2019, there were typhoons, earthquakes, and Taal erupted. The question in my mind always is - is Dasmariñas City ready? Are we responding well? Are we equipped? Sadly, it's negative.)

As of the moment, OIC Calado concludes that much needs to be done, especially when it comes to procurement of equipment and education/training of people to handle disasters because as compared to Bacoor City, Dasmariñas accordingly has virtually no equipment, not even searchlights and depository/warehouses of vehicles and equipment procured. The collapse of the wall in the subdivision in Langkaan and the fires in Bautista showed the weaknesses of the CDDRM. This does not even include the need for an office solely for the CDRRM, so its personnel can function well.

OIC Calado likewise affirms what Councilor Roman Cruz (not his real name) expressed that the informal settlers of Dasmariñas City are not excluded from services that the city government provides for its constituents. Both reiterated that Dasmariñas City ensures that social services do not 
discriminate between legitimate residents and informal settlers for as long as one is a Dasmariñas citizen, whose address is in Dasmariñas, one is entitled to the privileges for bonafide Dasmarineños. The informal settlers are compensated if their houses need to be dismantled to give way to city projects, such as road widening. The informal settlers receive money and are given the responsibility to relocate instead of relocating them. This way, they cannot complain that they are relocated in places that marginalizes them further such as far-flung areas where there's no employment, schools for their children, no water supply, etc.

Both Kagawad Cruz and OIC Calado also believe that the lack of electricity and water in areas where informal settlers reside will be remedied shortly because starting February 2021, road widening projects most often identify the needs of communities, and these are noted and are acted upon. The involvement of the government in the affairs of informal settlers was also documented by Balgos (2016). In Disaster governance in urbanizing Asia, Balgos expressed that securing the safety of informal settler families along waterways in Metro Manila involved the collaborative effort of a Government-civil society organization partnership. The study further stated that the state's political will, commitment, and social accountability are imperative to accelerate the process of urban resiliency and sustain the gains of collaborative governance.

The lack of government support negatively impacts the lives of informal settlers. Kyed (2019) noted that the lack of state support would compel the informal settlers to get by and improve their tenure and livelihood situation by engaging various "native" ward leaders, landowners, religious leaders, and political parties. In Malaysia, these groups assist the newcomer migrants and settlers in informal ways to access registration papers and land, while they are also benefitting in terms of small incomes and power from the informal status and insecurities facing the informal settlers. Overall, this leads to the prevalence of different forms of informal governance. Even though the informal settlers are well aware that they cannot get formal access to public services because they reside on illegal land, there is a small hope that one day the government may recognize their areas.

\section{Barangay Salitran 4's Response}

In the November 2020 Barangay Assembly, 122 (in uniform shirts) persons represented different sectors and organizations within barangay Salitran 4. The timing of the assembly is incidentally following two typhoons that ravaged the Philippines: typhoon Rolly of which the Cavite governor placed the province under a "state of calamity" because the region experienced Tropical Cyclone Wind Signal No. 4, and typhoon Ulysses on November 11, which is considered Tropical Cyclone Wind Signal No. 3, yet more deadly overall compared to Rolly. Once again, the Provincial Government of Cavite declared the province under a "State of Calamity" after the onslaught of Tropical Storm "Ulysses."

Interestingly, the barangay chairman's report included many issues and concerns affecting the people but mainly pertaining to usual mundane events and the social distancing protocol and nothing on the typhoon effects. However, chairman Jose Lopez (not his real name) started his talk to assure that full disclosure, transparency, and accountability are practices he abides by. Hence, his task is to report to the barangay folks what has been of most significant concern: Social Amelioration Program (SAP) of DSWD benefited 1263 families, modular education to pre-school daycare, resumption of road clearing, a vaccine for dogs, and prohibition of Christmas caroling and parties. In the open forum part of the discussion, the residents were given a chance to air out their concerns and ask questions, but no one did.

\section{CONCLUSION}

Sitio Bato reflects how the city government of Dasmariñas City handles informal settlers: eviction is not an action done to manage their proliferation, and hence, the people have no fear of having no place to live. This might be because the city's history of having been restructured to accommodate informal settlers from the National Capital Region has taught valuable lessons on handling them. Likewise, the informal settlers are an integral part of the history of Dasmarinas, and this perhaps has made the government impose soft policies towards their case. 
It is also apparent that no discrimination is felt and experienced by the informal settlers. They have not been "othered" as the social/public services for the legitimate residents of the city are also available to them. This might explain the seeming lack of concern of the residents of Sitio Bato for disasters, natural or man-made. Despite the surface precariousness of the area due mainly to the creek that passes through the community, residents swear that even super typhoons do not cause the stream to overflow and delude their houses.

More importantly, with enough knowledge of what causes typhoons, with a positive attitude towards their membership in the barangay despite being informal settlers and their preventive practices of planting trees and shunning trash disposal in the creek, the residents of Sitio Bato appear NOT to be living precariously. It could be surmised that since the barangay is not subject to frequent disasters, it is thus possible to create a sense of apathy within the community members, especially when their socio-economic situation is factored in. In other words, their efforts are more directed towards surviving from day to day, which is a tad harder with no electricity and with high water costs. On the part of the local government, the evident lack of discussion of the recent calamities tells how, in general, the city handles the DRRM: unless solicited, there is no response or intervention. Although no harsh measures intentionally discriminate against the informal settlers.

\section{REFERENCES}

Aliu, I. R., Akoteyon, I. S., \& Soladoye, O. (2021). Living on the margins: Socio-spatial characterization of residential and water deprivations in Lagos informal settlements, Nigeria. Habitat International, 107, 102293. https://doi.org/10.1016/j.habitatint.2020.102293

Apilado-Cañete, P. R. F. (2007). Place making and the politics of identity in a resettlement site in Dasmarinas, Cavite. University of the Philippines Diliman.

Bahagia, B., Mangunjaya, F. M., Wibowo, R., Rangkuti, Z., \& Alwahid, M. A. (2020). Leuit and prohibition forest: Indigenous knowledge of an Urug community resilience. Harmoni Sosial: Jurnal Pendidikan IPS, 7(2), 130-140. https://doi.org/10.21831/hsjpi.v7i2.33055

Balgos, B. C. (2016). Securing the safety of informal settler families along waterways in Metro Manila, Philippines: Government-civil society organisation partnership. In M. Douglass \& M. A. Miller (Eds.), Disaster Governance in Urbanising Asia (pp. 177-193). https://doi.org/10.1007/978-981-287-649-2_9

Bhattacharjee, S. (2018). "Where goes the waste?" a Knowledge, Attitude, and Practice (KAP) study on disposal of household waste. Open Access International Journal of Science \& Engineering, 3(1), 2456-3293. Retrieved from https://www.researchgate.net/publication/333774159_\%27WHERE_GOES_THE_WASTE\% 27 A_KNOWLEDGE_ATTITUDE_AND_PRACTICE_KAP_STUDY_ON_DISPOSAL_O F_HOUSEHOLD_WASTE

Castel, R. (1997). Las metamorfosis de la cuestión social: Una crónica del salariado. Ediciones Paidos Iberica.

de Leon, E. G., \& Pittock, J. (2017). Integrating climate change adaptation and climate-related disaster risk-reduction policy in developing countries: A case study in the Philippines. Climate and Development, 9(5), 471-478. https://doi.org/10.1080/17565529.2016.1174659

Gaillard, J.-C., \& Cadag, J. R. (2009). From marginality to further marginalization: Experiences from the victims of the July 2000 Payatas trashslide in the Philippines. Jàmbá: Journal of Disaster Risk Studies, 2(3), 197-215. https://doi.org/10.4102/jamba.v2i3.27

Iglesias, G. (2008). Flood disaster mitigation and river rehabilitation by Marikina City, Philippines. Safer Cities.

Kamerman, S. B., Neuman, M., Waldfogel, J., \& Brooks-Gunn, J. (2003). Social policies, family types and child outcomes in selected OECD countries. In OECD Social, Employment and Migration Working Papers (No. 6). https://doi.org/10.1787/625063031050 
Karaos, A. M., Nicolas, G., \& Rabacal, G. A. (2011). Innovative urban tenure in the Philippines: Challenges, approaches and institutionalization. Kenya: United Nations Human Settlements Programme (UN-HABITAT).

Kyed, H. M. (2019). Informal settlements and migrant challenges in Yangon. Moussons, 33, 65-94. https://doi.org/10.4000/moussons.4909

Lo, D., Franta, B., Roa-Quiaoit, H., \& Narisma, G. (2016). Climate disasters in the Philippines: a case study of immediate causes and root drivers from Cagayan de Oro, Mindanao and Tropical Storm Sendong/Washi. Cambridge: Harvard University.

Marmot, M. (2005). Social determinants of health inequalities. The Lancet, 365(9464), 1099-1104. https://doi.org/https://doi.org/10.1016/S0140-6736(05)71146-6

Palanca, J. T. (2014). On getting to know the Filipino informal settler. Retrieved January 10, 2013, from https:/tjpalanca.com/posts/2014-02-02-filipino-informal-settlers/

Rodgers, G., Gore, C., \& Figueiredo, J. B. (Eds.). (1995). Social exclusion: Rhetoric reality responses. Geneva: International Institute for Labour Studie.

Sejati, A. E., Hasan, M., \& Hidayati, D. N. (2021). The level participation in efforts mount Kelud eruption disaster mitigation in East Java. Harmoni Sosial: Jurnal Pendidikan IPS, 8(1), 100 106. https://doi.org/10.21831/hsjpi.v6i1.27847

UN-Habitat. (2003). The challenge of slums: global report on human settlements. Kenya: United Nations Human Settlements Programme.

Winayanti, L., \& Lang, H. C. (2004). Provision of urban services in an informal settlement: A case study of Kampung Penas Tanggul, Jakarta. Habitat International, 28(1), 41-65. https://doi.org/https://doi.org/10.1016/S0197-3975(02)00072-3 